\title{
Sustainablility Settlement Throught Recycle "Happa" In Kampung Belakang, Kamal, West Jakarta
}

\author{
Anggraeni Dyah ${ }^{1}$, Harfa Iskandaria ${ }^{2}$ \\ \{anggraeni.dyah@budiluhr.ac.id ${ }^{1}$, hiskandaria@gmail.com² ${ }^{2}$ \\ Budi Luhur University, Jalan Raya Ciledug Petukangan Utara, DKI Jakarta, Indonesia ${ }^{1,2}$
}

\begin{abstract}
Kampung Belakang is located in Kamal Village, Kalideres Sub district, West Jakarta. Kampung Belakang was reported as one of the slum areas by BPS (Biro Pusat Statistik) in DKI Jakarta.The dominant factor is the unhealthy lifestyle of people who carelessly throw garbage at any place. There are several places that turn to be garbage heap locations, such as in the river and drainage which become illegal waste disposal.Waste that is not well-managed in residential locations will have an impact on public health by causing various diseases. This problem is solved by using method of mentoring to the community to change the lifestyle of the community in order to process waste independently. The leaf of the trees is one type of organic waste. Burning it can cause pollution. So, one of the types of recycle for leaf is "Happa".In japan, Happa means is art from bone leaves. With a combination of textile dyes, Happa can be made into several art items such as bouquet or painting. Happa production can also be exported to Japan, mentoring to the community in Kampung Belakang to recycle the leaf litter into Happa, a solution to the problem of organic waste in this kampong. Community independence to process leaf waste in the environment, then the recycled Happa waste can be sold or exported to Japan. Until sales proceeds can increase economic value of society, so the impression of slums can be eliminated from Kampung Belakang.
\end{abstract}

Keywords: Happa, Sustainability Settlement, Recycle.

\section{Introduction}

Garbage is a common issues in all cities in the world and DKI Jakarta is one of the big cities that are facing the problem of increasing the volume of waste. Waste has become a national problem so it needs to be managed comprehensively and integrated from upstream to downstream in order to provide benefits economically, healthy for the community, and safe for the environment, and can change people's behavior [1].

Increasing the number of people on earth leads to increasing amount of waste that will be generated. The presence of waste brings many negative impacts in human life, such as causing odors, causing illness, flood, and contributing to global warming. Another problem is the limited land available to accommodate and process waste, especially in DKI Jakarta [2].

DKI Jakarta area that has problems with garbage is Kampung Belakang, Kamal village, Kalideres Sub district, West Jakarta. This can be seen from several areas of the Kampung Belakang which became the landfill. In addition, the drainage around the residential area is inadequate. A lot of waste is discharged on the drainage or river in the area of the Kampung Belakang. This affects the clogging of drainage and river channels that result in submerged water and flooding [3]. 
The community members also have no enough knowledge of impact of waste on health. Therefore, every household waste production is always dumped on the roadside, empty land, drainage and river. While leaf litter is collected, afterwardsit is burned. The activities of residents in processing waste affected the air pollution and disease sources [4].

To solve the waste problem in Kampung Belakang, there is counseling for Kampung Belakang, Kamal village, Kalideres sub-district, West Jakarta. In this activity, the community members will get the knowledge to recycle the leaf organic waste into a dry leaf frame or in Japan called "Happa". With a combination of textile dyes, Happa can be processed into decorative items.

After the community members have the ability to recycle their organic leaf waste into Happa, then they can produce and sell the Happa. In the end, it can improve people's economy and can solve waste problem in Kampung Belakang [5].

\subsection{Problems}

The problem of Kampung Belakang, Kamal village, Kalideres sub-district, West Jakarta community is lack of knowledge to recycle leaf organic waste into reusable goods.

\subsection{Objectives}

The purpose of assistance and counseling activities for Kampung Belakang, Kamal village, Kalideres sub-district, West Jakarta are:

- Community empowerment through recycling leaf organic waste into Happa;

- Community empowerment through the utilization of Happa to be decoration.

\subsection{Output}

To solve the problems of the community members of Kampung Belakang , Kamal village, Kalideres sub-district, West Jakarta, and then the output is that the community members know how to recycle the organic waste of leaves into Happa and make use of Happa into decoration.

\subsection{Benefits of Method}

To solve the problems of Kampung Belakang, Kamal village, Kalideres sub-district, West Jakarta, then the output is that the community will know how to recycle the organic waste of leaves into Happa and use Happa into decoration.

\section{Mentoring Method}

Left Waste Recycling Counseling Activity Becomes Happa for Kampung Belakang Community of Kamal Village, Kalideres sub-district West Jakarta, using approach process with TRI-POWER concept [6]. 


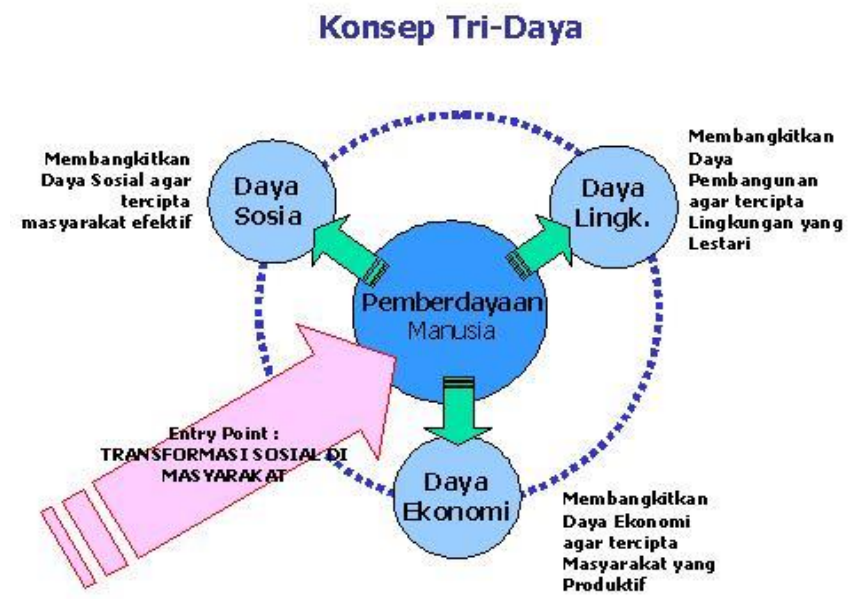

Fig. 1. Tri-Daya Concept.

Social Power Concept is to invite people through approach:

- Coordination with community leaders;

- Coordination with KSM (self-help group) Nyiur assisted by Budi Luhur University related to the development of Kampung Belakang.

The concept of Environmental Power is to identify:

- The habit of the community in imposing organic waste leaf;

- The ability of people to recycle leaf organic waste.

The concept of Economic Power is the result of recycling production of leaf organic waste into Happacan be used by the community themselves or sold, which can improve the economy of the surrounding community [7].

By applying the concept of Tri Daya on mentoring activities, Leaf Waste Recycling Becomes Happa for Kampung Belakang , Kamal village, Kalideres sub-district, West Jakarta, the stages of implementation activities are as follows:

- Permission to the administrators of Kampung Belakang, Kamal village, Kalideres subdistrict, West Jakarta to carry out the mentoring program;

- MoU Cooperation agreement with the management of KSM Nyiur assisted by Budi Luhur University as the developer of Kamal village, Kalideres sub-district, West Jakarta to carry out the mentoring program;

- Site survey for the implementation of mentoring activities;

- Make material mentoring (Leaf litter into Happa and the use of Happa becomes a decoration);

- Workshop leaf waste to become Happa;

- Workshop making decoration from happa;

- Making final report. 


\section{Kampung Belakang Kamal Jakarta Barat}

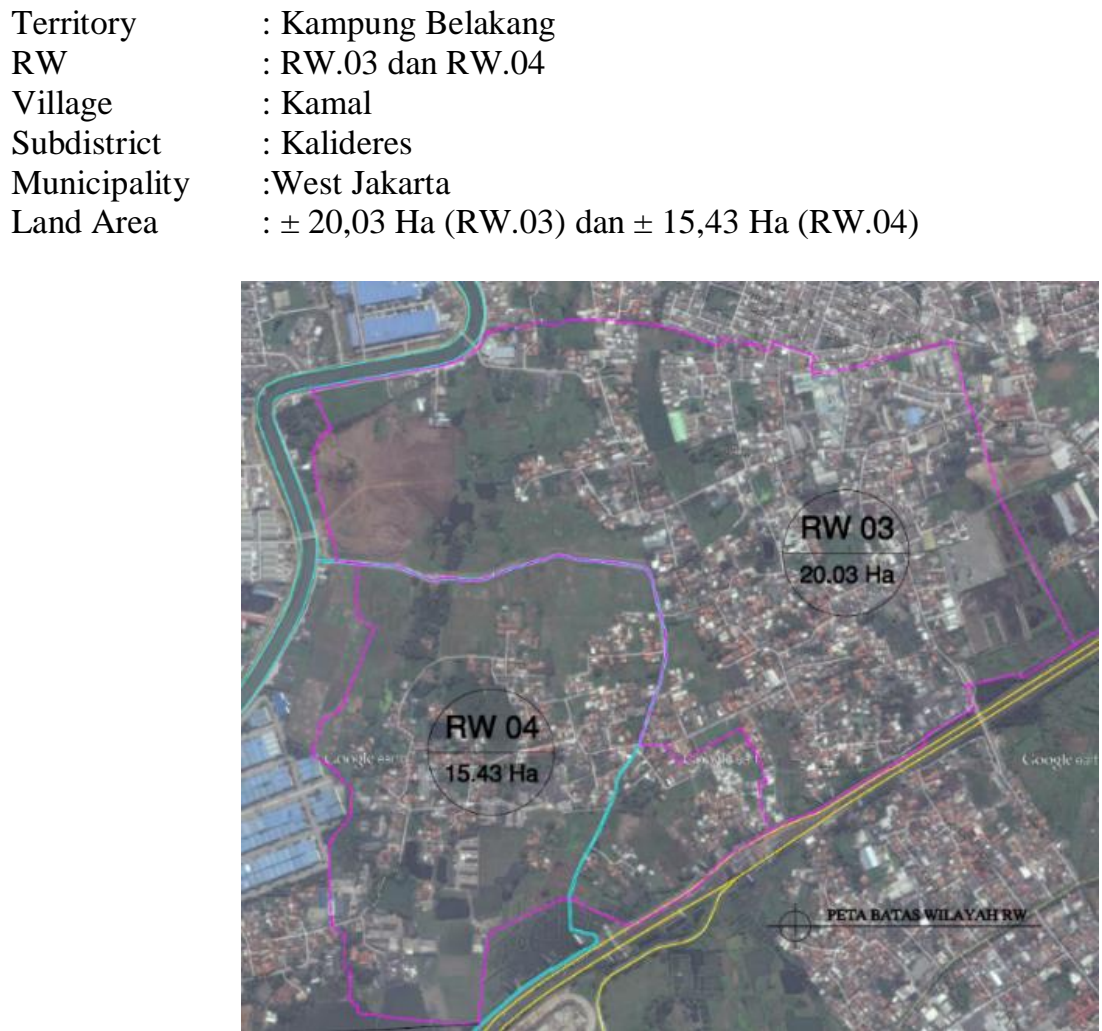

Fig. 2. Kampung Belakang Kamal West Jakarta.

Lack of public knowledge of the impact of waste in health, the cause of society does not manage the existing waste environment. This is known from the existence of several points in the area of Kampung Belakang which became the landfill. 


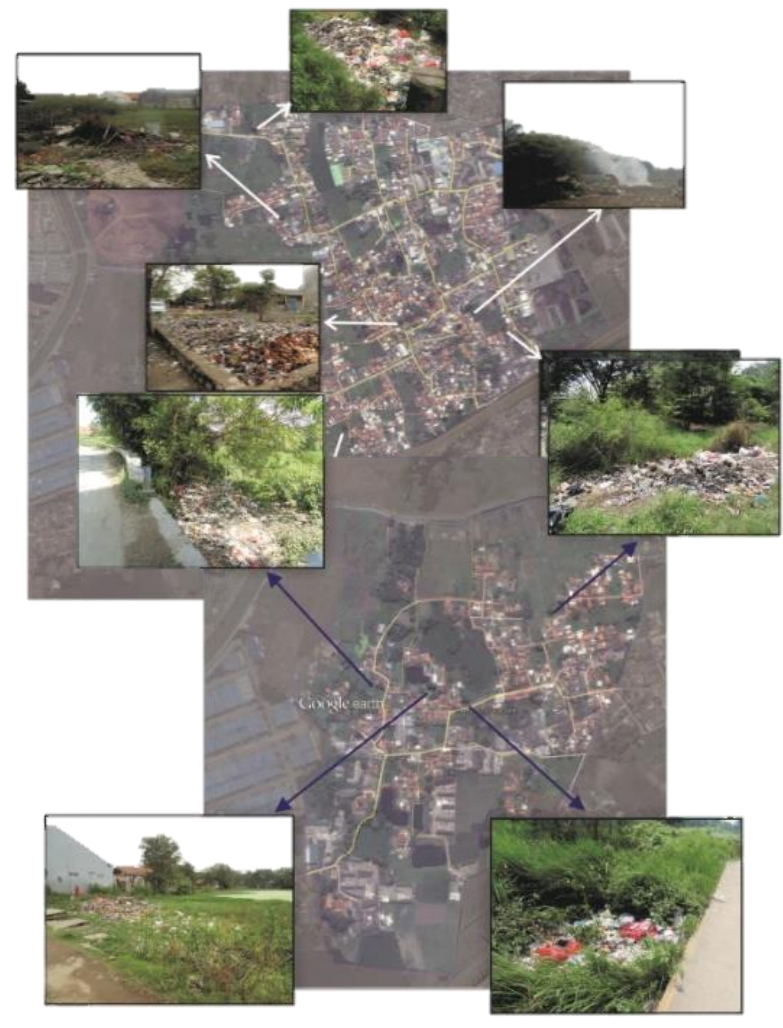

Fig. 3. Landfill.

Some drainages and rivers does not comply health requirements because a lot of waste piles. So that drainage and river become clogged the impact of the emergence of puddles and flood [8].
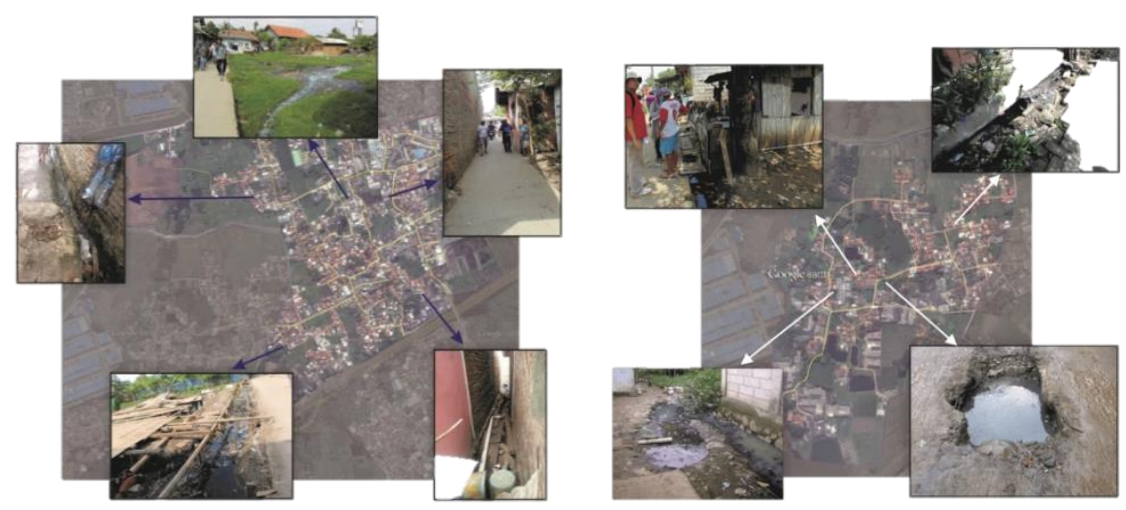

Fig. 4. Drainage. 


\section{Recycling Leaf Waste Becomes Happa}

The problem of Kampung Belakang community is to process leaf waste by collecting and burning, so that the impact of air pollution that can interfere with health. Thus, it is necessary to conduct counseling to utilize the leaf waste into reusable goods.

To make leaf waste into goods that can be reused, then the leaf litter must be recycled first into a framework of dry leaves or called with Happa. The process of making organic waste leaves into Happa is as follows [9]:

- Collect organic garbage leaves that are still green;

- Prepare natural mud in containers. Mud is a media of fermentation of organic green leaf waste into a framework of dried leaves or Happa. Based on research conducted by the University of Budi Luhur and KSM Nyiur, mud from catfish farms have faster fermentation ability;

- Soak the green leaf organic waste in a container containing natural mud. If using ordinary sludge, the fermentation process takes 2 months. If using mud from catfish farm, fermentation process only takes 3 days;

- After the green leaf organic waste fermentation process into a framework of dried leaves or Happa, then Happa can be washed and drained water. Happa's hatching aims to remove the mud and clean up the remaining green leaves that still stick to Happa. It was only later that Happa was drained to remove the water content of Happa;

- Prepare the water in the container;

- Boil Happa in the container and give the food colouring as needed. Colouring on Happa by boiling in water that has been given food colouring;

- After Happa changes color, move Happa from the container and drain the water;

- The final stage is the process of drying Happa. Happa can be naturally dried by drying in the sun.

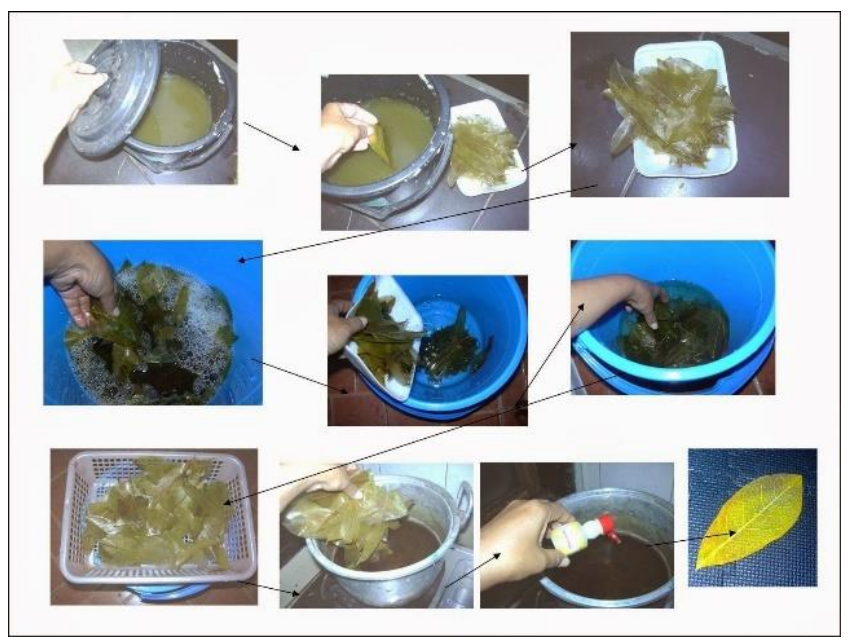

Fig. 5. The Process of Making Organic Waste Leaves into Happa. 
After the green leaf organic waste undergoes a fermentation process into a dry leaf frame or Happa, then Happa can be reused into goods can be used again in the form of decoration. Some of the ornaments that can be made from Happa are as follows:

- Happa as a painting media;

- Happa as a painting of handycraft;

- Bouquet of flowers from Happa;

- Lampshade from Happa;

- Paintings from Happa.

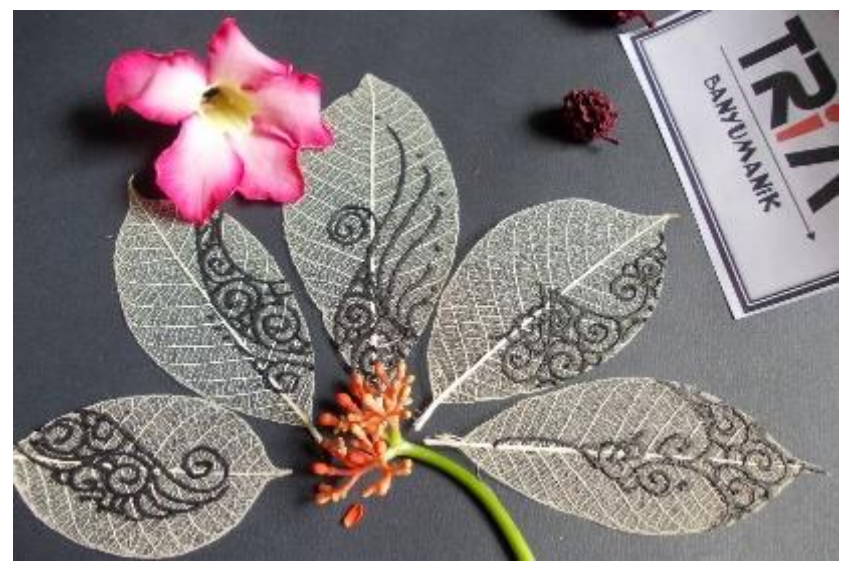

Fig. 6. Happa as a painting media.
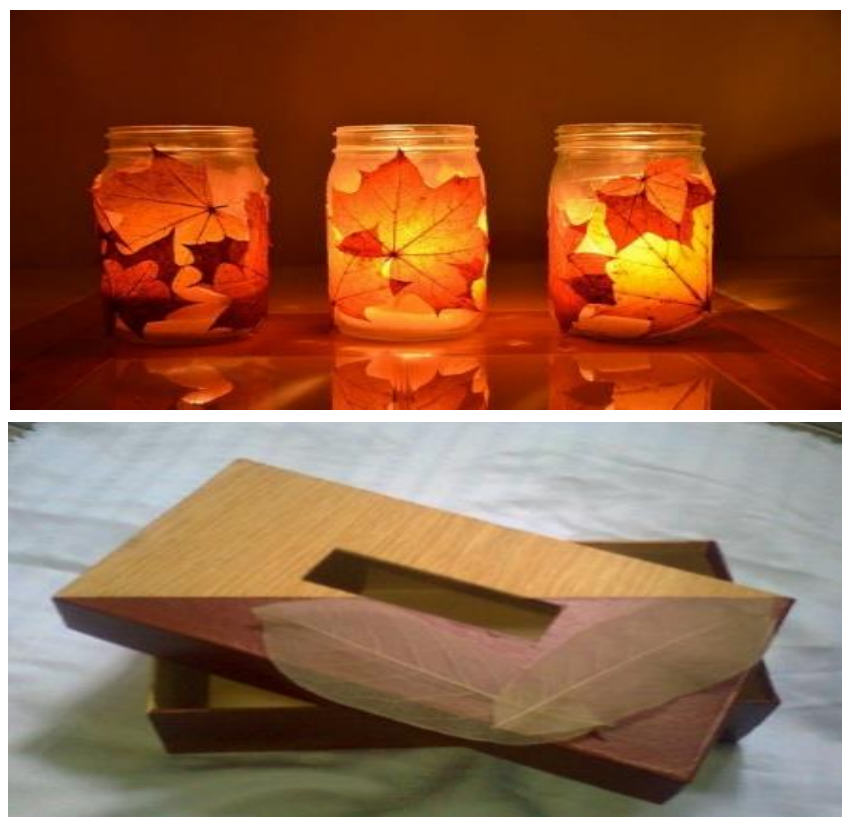

Fig. 7. Happa as a painting of handycraft. 


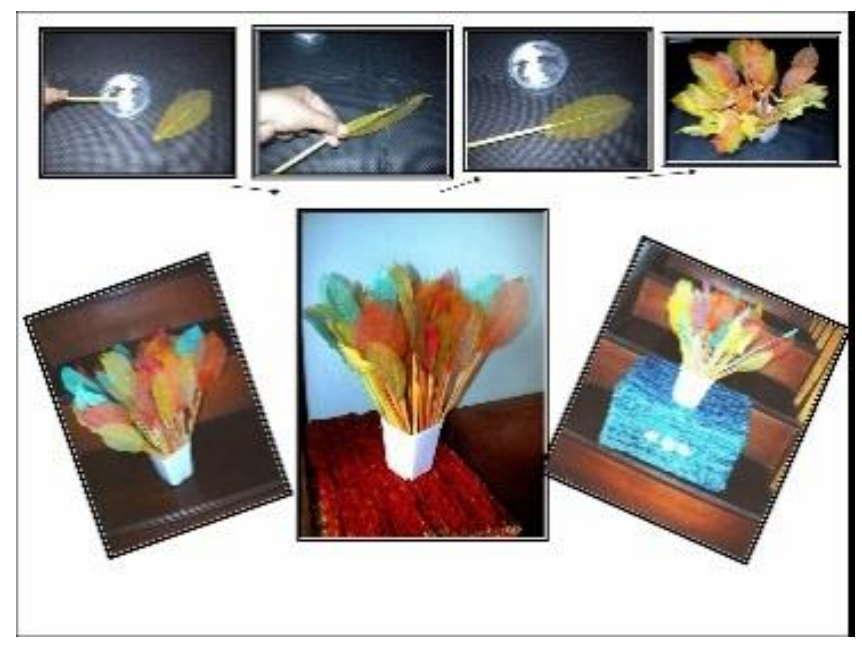

Fig. 8. Bouquet of flowers from Happa.

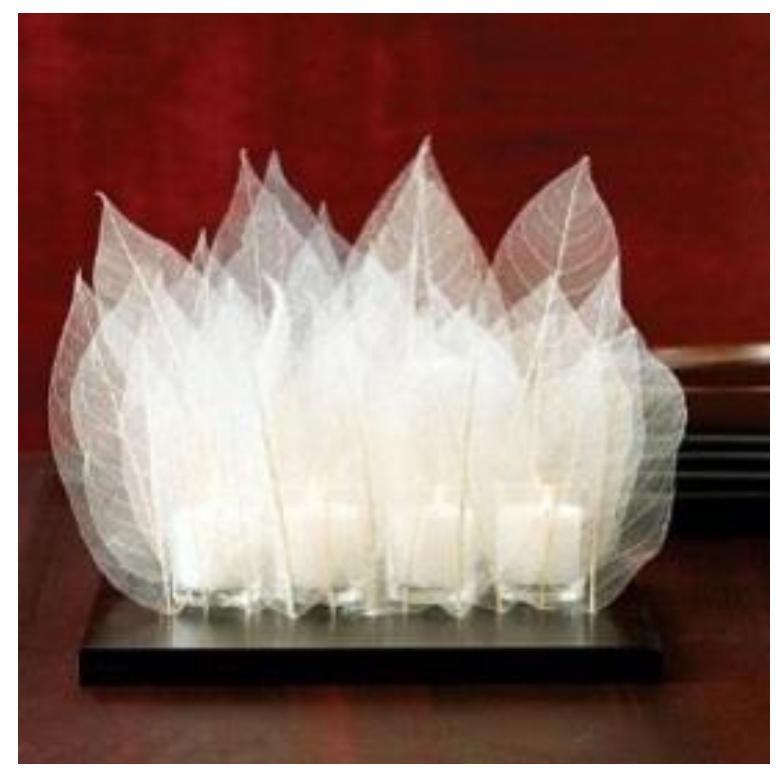

Fig. 9. Lampshade from Happa. 


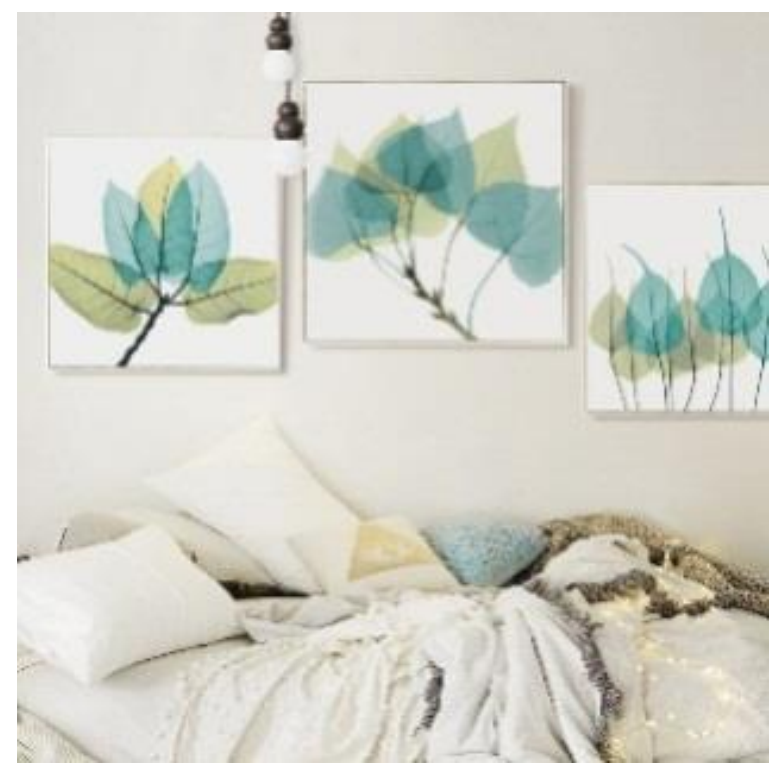

Fig. 10. Paintings from Happa.

\section{Conclusion}

One of the waste that become problem in KampungBelakang is leaf organic waste. During this time people collect organic waste leaves to be burned. Burning results cause air pollution that interferes with respiratory health.

In order for leaf organic waste can be recycled into goods that are reused; it takes the participation of administrators and all citizens to change the cultural pattern. The consultation was carried out in collaboration with KSM Nyiur assisted by Budi Luhur University who has had experience in recycling organic waste of leaf into dry or Happa leaf frame.

The community self-help can collect leaf organic waste and process it into Happa. Society can be creative to make Happa become decoration according to their ability. The results of Happa's creations can be used by the community or sold to the wider community, which in turn can improve the economy of the community.

Happa became one of the solutions of leaf organic waste problem for Kampung Belakang, Kamal Village, Kalideres Sub-district Jakarta Barat community.

\section{References}

[1]Rizqi Puteri Mahyudin, "Strategi Pengelolaan Sampah Berkelanjutan," EnviroScienteae, vol. 10, no. 1, pp. 33-40, 2014.

[2]N. D. Kurniasari, "Program CSR Berbasis Pemberdayaan Masyarakat (Untuk meningkatkan Produktivitas Usaha Mikro, Kecil, Menengah di Madura)," J. NeO Bis Vol. 9 No.1 2015., vol. 9 No.1, 2015.

[3]Hartuti Purnaweni, "Kebijakan Pengelolaan Lingkungan Di Kawasan Kendeng Utara Provinsi Jawa Tengah,” J. ILMU Lingkung., vol. 12, no. 1, 2014.

[4]I. Sangalang1 and ; Fredyantoni F. Adji2, "Pengaruh Kondisi Hunian Dan Lingkungan Terhadap 
Keberlanjutan Permukiman Tepi Sungai Studi Kasus: Kampung Pahandut Dan Desa Danau Tundai Di Kota Palangka Raya," J. Perspekt. Arsit., vol. 9, no. 2, pp. 47-58, 2014.

[5]Herry Fitriansah, "Keberlanjutan Pengelolaan Lingkungan Pesisir Melalui Pemberdayaan Masyarakat di Desa Kwala Lama Kabupaten Serdang Bedagai,” J. Pembang. Wil. dan Kota, vol. 8, no. 4, pp. 360-370, 2012.

[6]Sugiyono, Metode Penelitian Kuantitatif, Kualitatif, dan R \& D. Bandung: Alfabeta, 2011.

[7]Sarah Rainy A. Hutagalung, "Pengelolaan Lingkungan Untuk Keberlanjutan Pengembangan Ekonomi Lokal Di Sentra Industri Penyamakan Kulit Garut,” Perenc. Wil. dan Kota, vol. 21, no. 1, pp. 1-8, 2010.

[8]S. K. Putri Surandari, Anggraeni Dyah S, "IbM Menuju Kampung Petani Sampah di Kampung Belakang, Kelurahan Kamal, Kecamatan Kalideres, Jakarta Barat. Laporan PKM. Universitas Budi Luhur Jakarta,” 2017.

[9]T. A. Indra Riyanto, Putri Suryandari, "Proses Fermentasi Hijau daun menjadi Daun Transparan dengan Media Lumpur. Laporan Penelitian. Universitas Budi Luhur Jakarta.,” 2014. 